\title{
Aspirin inhibits the proliferation of human uterine leiomyoma cells by downregulation of K-Ras-p110 $\alpha$ interaction
}

\author{
MIN GAO $^{1^{*}}$, KAI-MIN GUO ${ }^{2 *}$, YING-MEI WEI $^{3}$, MING-MING MA $^{4}$, \\ JIA-RONG CAI ${ }^{5}$, TING-TING XIA ${ }^{6}$ and QING-JIAN YE ${ }^{7}$ \\ ${ }^{1}$ Department of Pharmacy, The Sixth Affiliated Hospital of Sun Yat-Sen University, Guangzhou, Guangdong 510655; \\ ${ }^{2}$ Department of Obstetrics and Gynecology, Guangzhou Women and Children's Medical Center, \\ Guangzhou Medical University, Guangzhou, Guangdong 510623; ${ }^{3}$ Department of Neurology, \\ Sun Yat-sen Memorial Hospital of Sun Yat-sen University, Guangzhou, Guangdong 510120; \\ ${ }^{4}$ Department of Pharmacology, Cardiac and Cerebral Vascular Research Center, \\ Zhongshan School of Medicine, Sun Yat-Sen University, Guangzhou, Guangdong 510080; \\ Departments of ${ }^{5}$ Urology, ${ }^{6}$ Infertility and Sexual Medicine, and ${ }^{7}$ Gynecology, \\ The Third Affiliated Hospital of Sun Yat-Sen University, Guangzhou, Guangdong 510630, P.R. China
}

Received March 15, 2017; Accepted August 14, 2017

DOI: 10.3892/or.2017.5915

\begin{abstract}
Aspirin has been confirmed as an effective antitumor drug in various cancers. However, the relationship between aspirin and uterine leiomyoma is still underexplored. Here, we explored the effects of aspirin on human uterine leiomyoma cells and provide insights into the underlying mechanisms. Cell Counting Kit-8 (CCK-8) and flow cytometry analysis showed that aspirin treatment inhibited cell proliferation and promoted cell cycle arrest at G0/G1 phase in a dose- and time-dependent manner of human uterine leiomyoma cells. Further studies revealed that aspirin blocked the interaction between K-Ras and $\mathrm{p} 110 \alpha$ by co-immunoprecipitation and immunofluorescence. Western blotting demonstrated K-Ras-p110 $\alpha$ interaction was required for the effects of aspirin-induced inhibition on cell growth and cell cycle transition via cell cycle regulators, including cyclin D1 and cyclin-dependent kinase 2 (CDK2). $\mathrm{PI} 3 \mathrm{~K} / \mathrm{Akt} / \mathrm{caspase}$ signaling pathway was involved in human uterine leiomyoma cell growth under aspirin treatment. Taken together, these results suggest that aspirin inhibited human uterine leiomyoma cell growth by regulating K-Ras-p110 $\alpha$
\end{abstract}

Correspondence to: Dr Qing-Jian Ye, Department of Gynecology, The Third Affiliated Hospital of Sun Yat-Sen University, 600 Tianhe Road, Guangzhou, Guangdong 510630, P.R. China

E-mail: yeqingjian@163.com

Dr Min Gao, Department of Pharmacy, The Sixth Affiliated Hospital of Sun Yat-Sen University, 26 Erheng Road of Yuan Village, Guangzhou, Guangdong 510655, P.R. China

E-mail: gaomin20040520@163.com

${ }^{*}$ Contributed equally

Key words: human uterine leiomyoma cell, aspirin, proliferation, K-Ras-p110 $\alpha$ interaction interaction. Aspirin which targeting on interaction between $\mathrm{K}$-Ras and $\mathrm{p} 110 \alpha$ may serve as a new therapeutic drug for uterine leiomyoma treatment.

\section{Introduction}

Uterine leiomyoma (fibroid) is one of the most common benign smooth muscle tumors with an estimated incidence of $75 \%$ in reproductive aged women and $\sim 25 \%$ of fertile women bear clinical symptoms, such as heavy or abnormal uterine bleeding, pelvic pain and infertility (1-3). Although surgical therapies, including myomectomy and hysterectomy, are frequently used for the management in fibroids, medical therapies are considered as the first-line treatment. Current medical managements, such as gonadotropin-releasing hormone $(\mathrm{GnRH})$ analogs, selective estrogen receptor modulators and ulipristal acetate, are used for reducing fibroid size and improving severe symptoms $(1,4)$.

Aspirin, the most commonly used non-steroidal antiinflammatory agent for the treatment of fever, pain or other inflammatory conditions, has been identified as a potential chemopreventive drug supported by epidemiological data or clinical trials (5-8). The accumulated evidence shows aspirin was related with the reduced risks of breast, lung, colorectal, skin, prostate and endometrial cancer (5,9-11). A study showed using a continuous low dose of aspirin daily decreased the risk of cancer distant metastasis (12). Several anti-proliferation mechanisms of aspirin involve inhibition of WNT- $\beta$-catenin signaling, suppression of PI3K/Akt signaling, modulation of Bax and Bcl-2 activation, and regulation of prostaglandin (PG) synthesis and catabolism (8,13-16). Although the antitumor effects of aspirin are associated with cell proliferation, the relationship between aspirin and uterine leiomyoma remains unclear.

Kirsten rat sarcoma-2 viral (v-Ki-ras2) oncogene homologue (K-Ras) mutations represent genetic defect found in 
various human cancers. Activated K-Ras signaling contributed to promoting tumor initiation and cell proliferation $(17,18)$. Previous studies supported the idea that simultaneous activation of phosphatidylinositol 3-kinase (PI3K) was essential for $\mathrm{K}$-Ras-induced tumorigenesis (19-21). It was indicated that a functional interaction K-Ras and PI3K p110 $\alpha$ (PI3K catalytic subunit) in host tissue was required for the growth-permissive environment for the tumor $(22,23)$. Di Magliano et al (24) demonstrated that K-Ras activation could be inhibited by aspirin. Several studies demonstrate that PI3K mutation serves as a predictive molecular biomarker for adjuvant aspirin therapy $(25,26)$. Thus, K-Ras or PI3K associated signaling pathway may be a key target of aspirin therapy for uterine leiomyoma.

In this study, we used human uterine leiomyoma cells to investigate the anti-proliferation function of aspirin and investigated the underlying mechanisms.

\section{Materials and methods}

Cell culture. Human uterine leiomyoma (UtLM) cells (GM10964) were obtained from Coriell Institute for Medical Research (Camdern, NJ, USA). Cells were incubated in culture medium: Medium 199 (Gibco, Grand Island, NY, USA) supplemented with $10 \%$ fetal bovine serum (Gibco), endothelial cell growth supplement (PromoCell, Heidelberg, Germany), heparin (Sigma-Aldrich, St. Louis, MO, USA), $10^{5} \mathrm{U} / 1$ penicillin and $100 \mathrm{mg} / \mathrm{l}$ streptomycin (Gibco) at $37^{\circ} \mathrm{C}$, in $5 \% \mathrm{CO}_{2}$. Upon reaching 70-80\% confluence, cells were subcultured with $0.1 \%$ trypsin with $0.02 \%$ EDTA (Gibco). Human uterine leiomyoma cells were used for the following experiments by aspirin (Sigma-Aldrich) treatment.

Reagents. Aspirin with a purity exceeding 98\% was purchased from Sigma-Aldrich. It was dissolved in distilled water at the desired concentrations.

Cell viability assay. Cell viability was assessed by Cell Counting Kit-8 (CCK-8, Dojindo Molecular Technologies, Kumamoto, Japan). Cells ( $5 \times 10^{3}$ cells/well) were seeded in a 96-well plate. Plates were pre-incubated for $24 \mathrm{~h}$ in a humidified incubator. Then the cells were serum starved for another $24 \mathrm{~h}$. Forty-eight hours after different treatments, $10 \%$ CCK-8 solution was added to each well of the plate and the plates were incubated for $2 \mathrm{~h}$ in the incubator. The absorbance was measured at $450 \mathrm{~nm}$ by BioTek microplate reader (Winooski, VT, USA).

Flow cytometry. Cell cycle was evaluated by flow cytometry. After appropriate treatment, cells were harvested, rinsed twice with phosphate-buffered-saline (PBS) and fixed in 70\% ethanol for $24 \mathrm{~h}$. Cells were incubated with $100 \mu \mathrm{l}$ RNase A solution (KeyGen Biotech, Nanjing, China) for $30 \mathrm{~min}$ at $37^{\circ} \mathrm{C}$ and were added with $400 \mu \mathrm{l}$ PI solution (KeyGen Biotech) for staining for $30 \mathrm{~min}$ in the dark. DNA content of cell distribution was analyzed at $488 \mathrm{~nm}$ by flow cytometry (EPICS XL-MCL; Beckman Coulter, Miami, FL, USA).

Western blot analysis. Total proteins were prepared from cultured human uterine leiomyoma cells. Protein was extracted with RIPA lysis buffer (Beyotime Biotechnology, Nantong, China) and protease inhibitor cocktail (Sigma-Aldrich). The protein content was evaluated using BCA Protein assay kit (Beyotime Biotechnology) and bovine serum albumin as the standard. Equal amounts of total protein were boiled and separated on SDS-PAGE gels (Beyotime Biotechnology) and transferred to PVDF membrane (Millipore, Bedford, MA, USA). The membranes were incubated with the blocking solution at room temperature for $1 \mathrm{~h}$. Then the membranes were incubated with primary antibodies against K-Ras (mouse monoclonal, 1:1,000; Sigma-Aldrich), p110 $\alpha$ (rabbit monoclonal, 1:1,000; Cell Signaling Technology, Beverly, MA, USA), p85 (rabbit monoclonal, 1:1,000; Cell Signaling Technology), p-p85 (Tyr-458, rabbit polyclonal, 1:1,000; Cell Signaling Technology), Akt (rabbit polyclonal, 1:1,000; Cell Signaling Technology), p-Akt (Ser-473, rabbit polyclonal, 1:1,000; Cell Signaling Technology), cyclin D1 (rabbit monoclonal, 1:1,000; Cell Signaling Technology), CDK2 (rabbit monoclonal, 1:1,000; Cell Signaling Technology), caspase-3 (rabbit monoclonal, 1:1,000; Cell Signaling Technology), caspase-9 (rabbit monoclonal, 1:1,000; Cell Signaling Technology), caspase-8 (rabbit monoclonal, 1:1,000; Cell Signaling Technology), caspase-12 (rabbit monoclonal, 1:1,000; Cell Signaling Technology), PARP (rabbit monoclonal, 1:1,000; Cell Signaling Technology), $\alpha$-tubulin (mouse monoclonal, 1:1,000; Sigma-Aldrich), his (mouse monoclonal, 1:1,000; Sigma-Aldrich), flag (rabbit monoclonal, 1:1,000; Sigma-Aldrich) for $24 \mathrm{~h}$ at $4^{\circ} \mathrm{C}$. Then the membranes were subsequently probed with respective secondary antibodies $(1: 2,000$, Cell Signaling Technology) for $1 \mathrm{~h}$ at room temperature. The protein band signals of target bands were detected by Bio-Rad Molecular Imager ChemiDoc XRS plus System (Bio-Rad, Richmond, CA, USA). Quantification of band intensities was measured via ImageJ software (National Institute of Health, Bethesda, MD, USA).

Co-immunoprecipitation. The cell lysates were extracted using non-denaturing lysis buffer. Co-immunoprecipitation (co-IP) was done using the Thermo Scientific Pierce co-IP kit. The antibodies were first immobilized for $2.5 \mathrm{~h}$ using AminoLink Plus coupling resin. The resin was then washed and incubated with cell lysate overnight. Then the resin was washed and protein eluted using elution buffer. Samples were resolved on SDS-PAGE gels (Beyotime Biotechnology) and transferred onto PVDF membranes (Millipore). The bound proteins were determined by immunoblotting with the indicated antibodies.

Plasmid transfection. Human uterine leiomyoma cells were seeded at a density of $\sim 1 \times 10^{5} / \mathrm{ml}$. After $24 \mathrm{~h}$, pEnter-his vector, pEnter-his-K-Ras and pEnter-flag-p110 $\alpha$ (Vigene Biosciences, Jinan, China) were transfected into the cells with Lipofectamine 2000 reagent (Invitrogen, Carlsbad, CA, USA). Plasmids and Lipofectamine 2000 reagent were diluted in serum and antibiotics free Opti-MEM ${ }^{\circledR}$ (Invitrogen) to form the transfection complexes, respectively, for $20 \mathrm{~min}$ at room temperature and then added to the cells. After incubation for $6 \mathrm{~h}$ at $37^{\circ} \mathrm{C}$, transfection complexes were replaced with DMEM containing 20\% fetal calf serum. Cells were prepared for following experiments after $48 \mathrm{~h}$. 

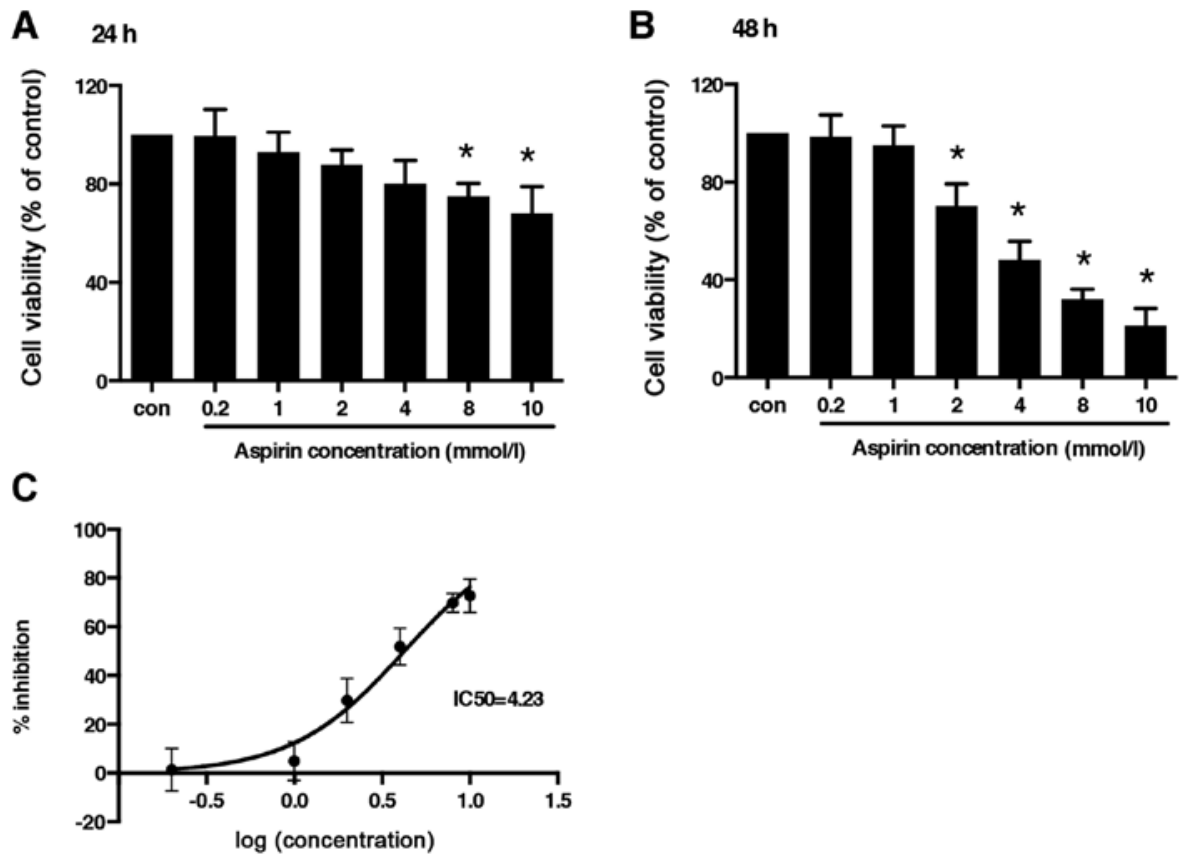

Figure 1. Aspirin inhibits human uterine leiomyoma cell growth. CCK8 analysis was used to measure the cell viability of human uterine leiomyoma cells after treatment with aspirin $(0.2,1,2,4,8$ or $10 \mathrm{mmol} / \mathrm{l})$ for $24 \mathrm{~h}(\mathrm{~A})$ and $48 \mathrm{~h}(\mathrm{~B})\left(\mathrm{n}=5-6,{ }^{*} \mathrm{P}<0.05 \mathrm{vs}\right.$ con). (C) Inhibitory dose-response curves to determine the $\mathrm{IC}_{50}$ for aspirin on cell viability after 48 -h treatment was calculated by non-linear regression using four-parameter logistic curves on GraphPad Prism 5 software $\left(\mathrm{n}=5-6,{ }^{*} \mathrm{P}<0.05\right.$ vs con). All values represent mean $\pm \mathrm{SD}$.

siRNA transfection. The siRNA duplexes against K-Ras gene synthesized by Ribobio (Guangzhou, China) were transiently transfected with Lipofectamine 2000 reagent (Invitrogen). Scramble RNA was used as negative control. Scramble RNA and K-Ras siRNA strands and Lipofectamine 2000 reagent were diluted in serum and antibiotic-free DMEM to form the transfection complexes for $10 \mathrm{~min}$ at room temperature and then were added to cells. After incubation for $6 \mathrm{~h}$ at $37^{\circ} \mathrm{C}$, transfection complexes were replaced with DMEM containing $20 \%$ fetal calf serum (Gibco). Cells were prepared for following experiments after $48 \mathrm{~h}$. The siRNA sequences for K-Ras are as follows: negative control: sense-5'-UUCUCCGAACGUGU CACGU-3'; antisense-5'-ACGUGACACGUUCGGAGAA-3'. KRAS siRNA: sense-5'-GUCUCUUGGAUAUUCUCGA-3'; antisense-5'-UCGAGAAUAUCCAAGAGAC-3'.

Immunofluorescence analysis. Immunofluorescence was performed to detect the effects of aspirin on the p110 $\alpha / \mathrm{K}$-Ras interaction. Human uterine leiomyoma cells cotransfected with his-K-Ras and flag-p110 $\alpha$ in confocal well were incubated with primary his and flag antibodies (1:100, Sigma-Aldrich) at $4^{\circ} \mathrm{C}$ overnight, followed by the incubation with secondary Cy3 anti-mouse or FITC anti-rabbit antibodies (1:200, Beyotime Biotechnology) at room temperature for $1 \mathrm{~h}$. Nuclei were stained with Hoechst (1:200, Beyotime Biotechnology) for $5 \mathrm{~min}$. Cells were photographed by confocal system (Olympus, Tokyo, Japan).

Statistical analysis. Raw data were applied directly in statistical analysis. Statistical analysis was calculated using GraphPad Prism 5 software (GraphPad Software, Inc., La Jolla, CA, USA). Collected data were presented as the mean \pm SD. Datasets with three or more groups were analyzed by one-way
ANOVA. Comparisons of two groups were analyzed by Student's two-tailed t-test. The level for statistical significance was 0.05 .

\section{Results}

Aspirin inhibits cell proliferation in human uterine leiomyoma cells. Human uterine leiomyoma (UtLM) cells (GM10964) obtained from Coriell Institute for Medical Research have been used widely for investigating cell proliferation of uterine leiomyoma in research as in vitro modeling system $(27,28)$. Therefore, we used this cell line for investigating the effects of aspirin on uterine leiomyoma.

To investigate the effects of aspirin on the growth of human uterine leiomyoma cells, human uterine leiomyoma cells were exposed to six different concentrations of aspirin $(0.2,1,2,4$, 8 and $10 \mathrm{mmol} / \mathrm{l}$ ) for 24 and $48 \mathrm{~h}$. CCK- 8 analysis was used to assess the effects of aspirin on cell viability. Aspirin induced a dose- and time-dependent inhibition in cell viability (Fig. 1). After treatment with 8 and $10 \mathrm{mmol} / \mathrm{l}$ aspirin for $24 \mathrm{~h}$, the cell number decreased to $75.09 \pm 5.18$ and $68.12 \pm 10.82 \%$ respectively, compared with control group (Fig. 1A). The cell number decreased to $70.28 \pm 8.98,48.12 \pm 7.65,32.23 \pm 3.87$ and $21.32 \pm 6.91 \%$ under the treatment with $2,4,8$ and $10 \mathrm{mmol} / \mathrm{l}$ aspirin for $48 \mathrm{~h}$, respectively (Fig. 1B). The half maximal inhibitory concentration $\left(\mathrm{IC}_{50}\right)$ (Fig. 1C) of aspirin for human uterine leiomyoma cells was $4.23 \mathrm{mmol} / \mathrm{l}$ at $48 \mathrm{~h}$ of incubation which was selected in the following experiments.

Effect of aspirin on cell cycle in human uterine leiomyoma cells. To investigate the underlying mechanisms of cell growth inhibition induced by aspirin in human uterine leiomyoma cells, we examined the effect of aspirin on cell cycle 
A

Aspirin (mmol/):

con

0.2

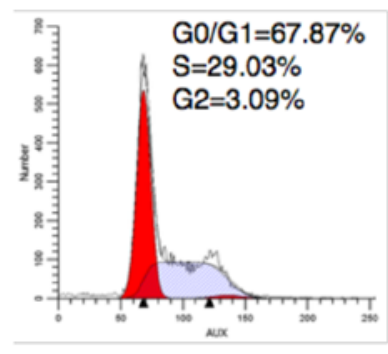

4

8
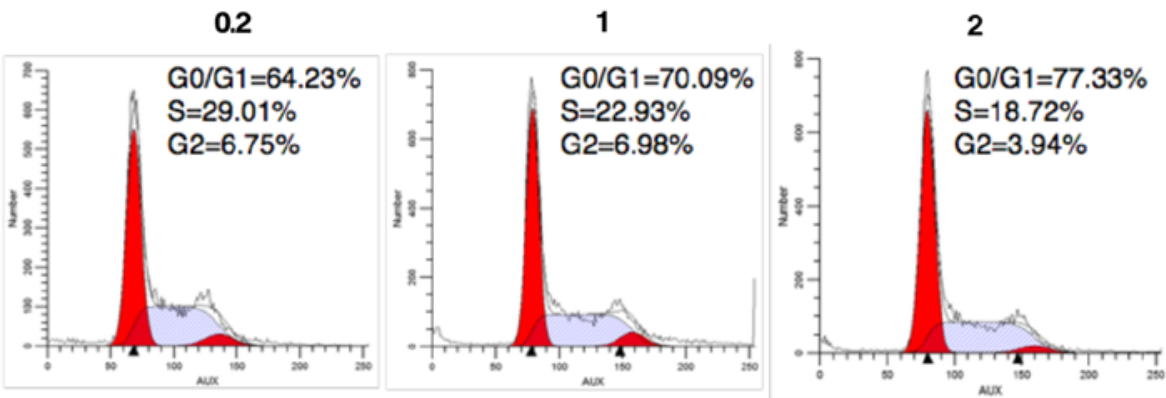

10
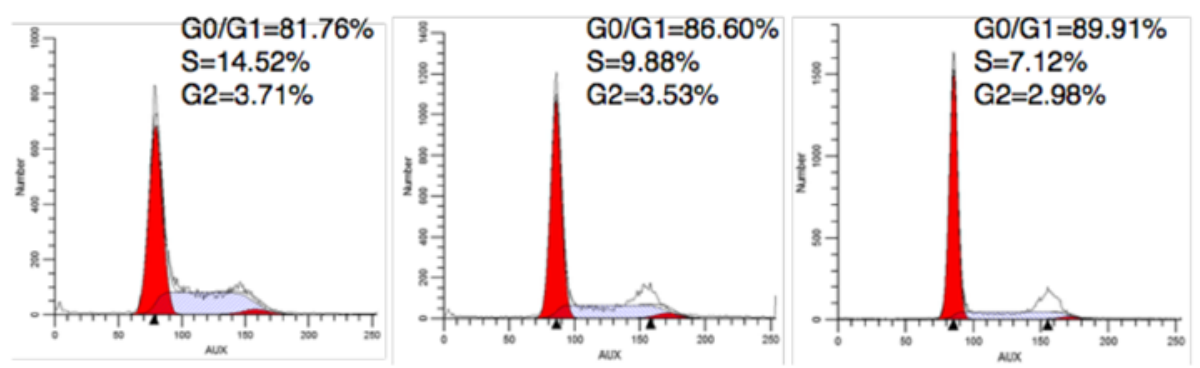

B

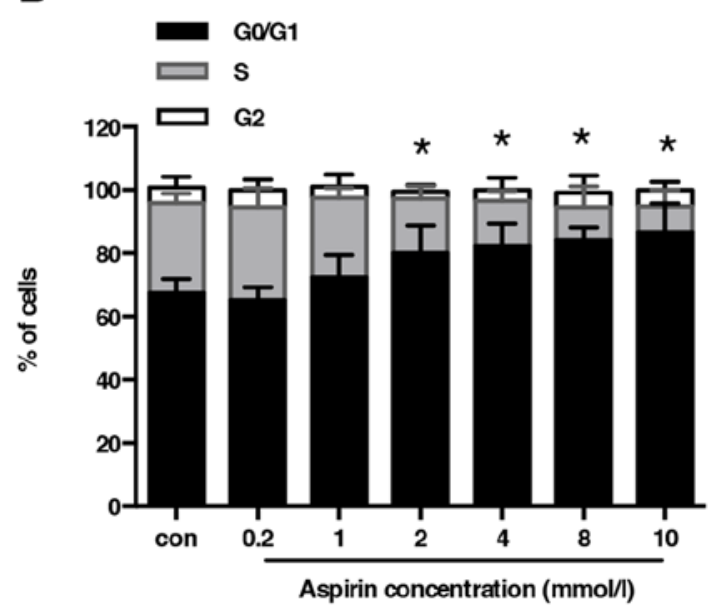

Figure 2. Aspirin inhibits G1/S transition in human uterine leiomyoma cells. (A) Flow cytometry analysis of cell cycle distribution induced by various concentrations of aspirin for $48 \mathrm{~h}$. (B) Percentage of cell number in different phases in cell cycle was determined by quantitative analysis ( $\mathrm{n}=6-7,{ }^{*} \mathrm{P}<0.05 \mathrm{vs}$ con). All values represent mean \pm SD.

distribution. Different concentrations of aspirin $(0.2,1,2,4$, 8 and $10 \mathrm{mmol} / \mathrm{l}$ ) were used for $48 \mathrm{~h}$ in human uterine leiomyoma cells (Fig. 2). The percentage of cells in the G0/G1 phase increased from $67.45 \pm 4.45$ to $80.01 \pm 8.80,82.33 \pm 7.09$, $84.12 \pm 4.15$ and $86.72 \pm 8.98 \%$ in aspirin treatment of $2,4,8$ and $10 \mathrm{mmol} / \mathrm{l}$ respectively. Aspirin decreased the cell population in the $\mathrm{S}$ phase from $28.45 \pm 3.03$ to $17.23 \pm 4.09,14.19 \pm 3.19$, $10.47 \pm 6.53$ and $8.12 \pm 5.17 \%$ in concentrations of $2,4,8$ and $10 \mathrm{mmol} / \mathrm{l}$ respectively. The data suggested aspirin inhibited the cell entrance from the $\mathrm{G} 0 / \mathrm{G} 1$ phase to the $\mathrm{S}$ phase.

Aspirin inhibits human uterine leiomyoma cell proliferation

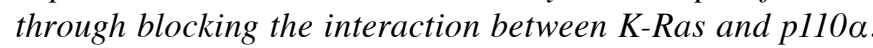
As reported, K-Ras was involved in various carcinomas and the interaction between PI3K p110 $\alpha$ and Ras was required in tumorigenesis (11). Our results illustrated that the phosphorylation of PI3K p85 and Akt as well as the expression of cell cycle associated protein, including cyclin D1 and CDK2 were decreased under the treatment of aspirin ( $4.23 \mathrm{mmol} / \mathrm{l})$ for $48 \mathrm{~h}$ (Fig. 3A). However, the protein expression of K-Ras and PI3K p110 $\alpha$ did not alter compared with control group (Fig. 3A). Then the K-Ras-p110 $\alpha$ interaction was detected (Fig. 3B). The interaction between K-Ras and p110 $\alpha$ was decreased significantly under treatment of aspirin. In cells transfected with flag-tagged $\mathrm{p} 110 \alpha$ and his-tagged $\mathrm{K}$-Ras plasmids, co-IP and confocal images also showed that aspirin reduced the interaction between $\mathrm{p} 110 \alpha$ and K-Ras (Fig. 3C and D). These findings implied that aspirin inhibited human uterine leiomyoma cell growth via reducing the interaction between $\mathrm{p} 110 \alpha$ and K-Ras. 
A

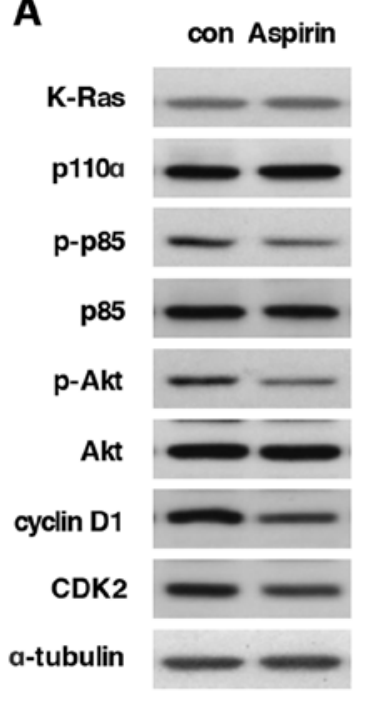

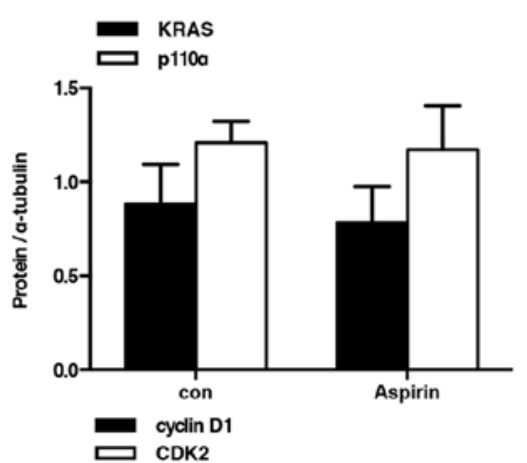

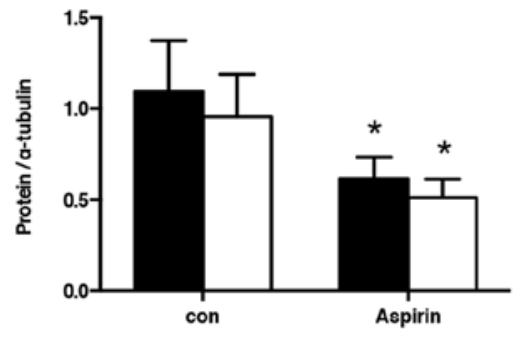

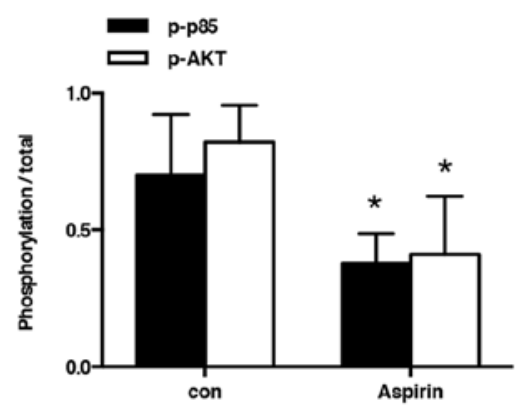

B

IP anti-p110a

con Aspirin IgG

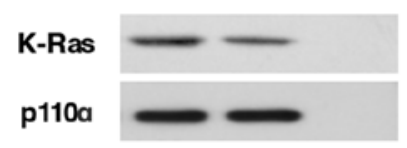

C

IP anti-flag
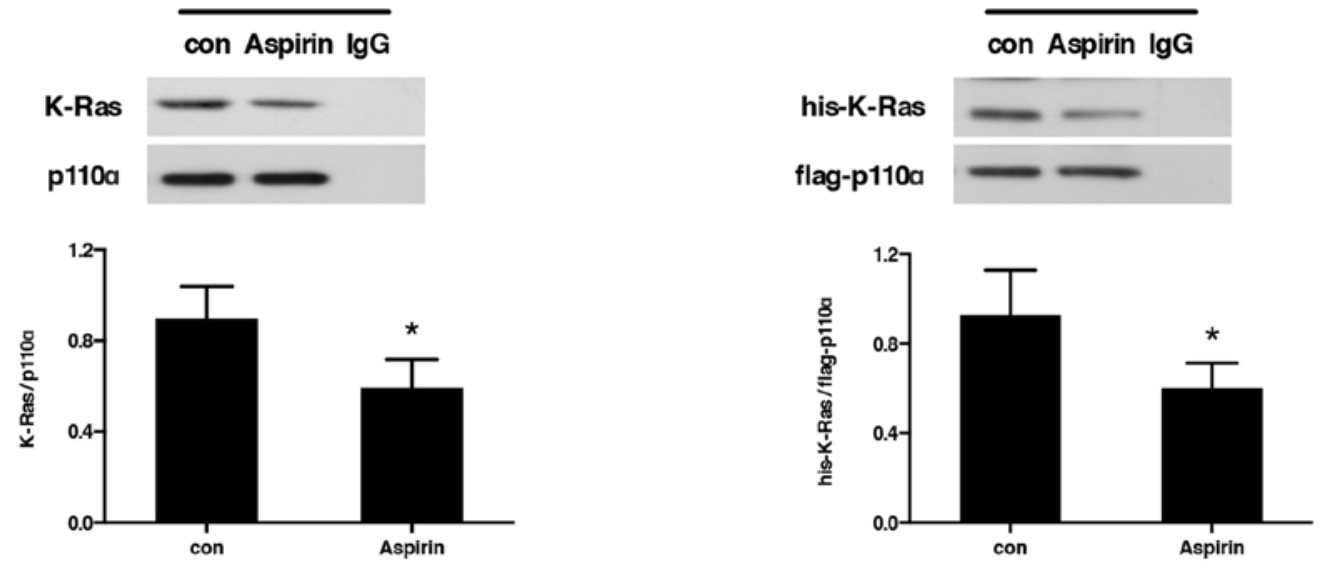

D
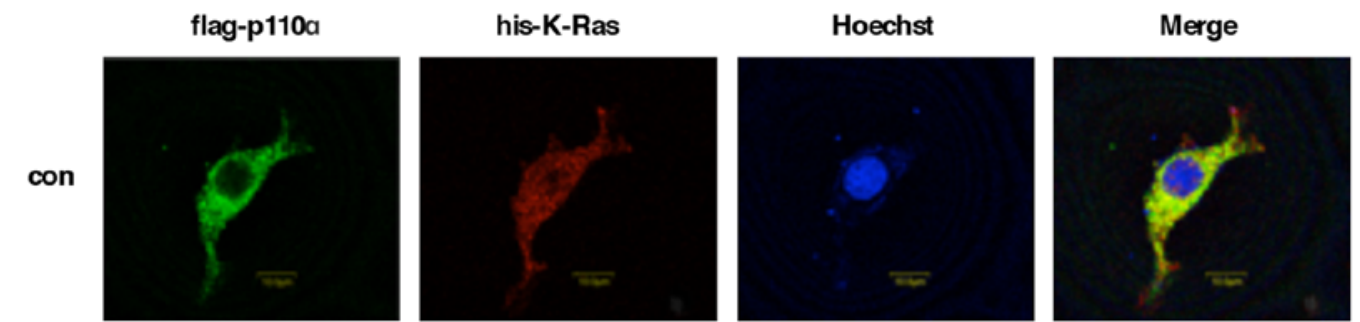

Aspirin
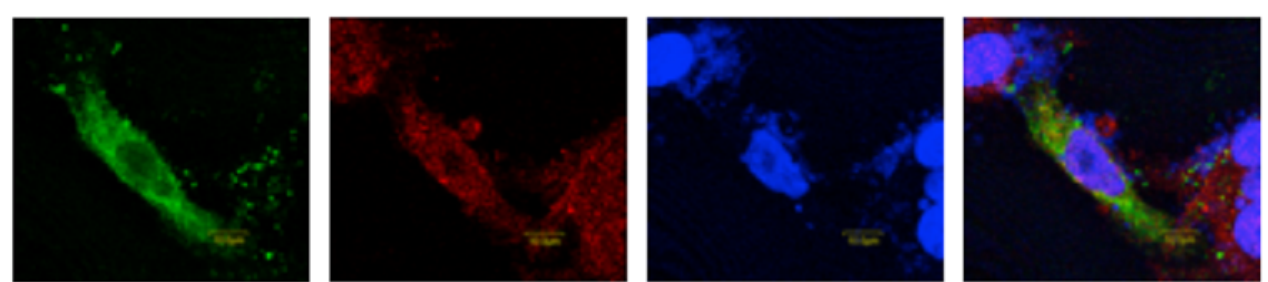

Figure 3. Aspirin blocks K-Ras-p110 $\alpha$ interaction in human uterine leiomyoma cells. (A) Western blot analysis of protein expression of human uterine leiomyoma cells under aspirin treatment $(4.23 \mathrm{mmol} / \mathrm{l})$ for $48 \mathrm{~h}$. Human uterine leiomyoma cell lysates were harvested for co-immunoprecipitated assays to detect the endogenous (B) and exogenous (C) interaction ( $\mathrm{n}=5$, ${ }^{*} \mathrm{P}<0.05$ vs con). (D) Confocal images showed K-Ras-p110 $\alpha$ interaction induced by aspirin. Green is for flag-p110 $\alpha$ and red is for his-K-Ras and yellow is for merge of green with red which accounted for the K-Ras-p110 $\alpha$ interaction (n=3). All values represent mean \pm SD. 
A

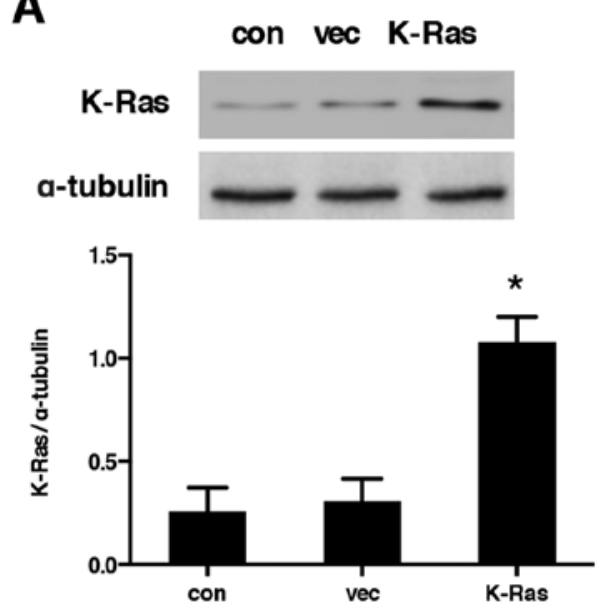

C

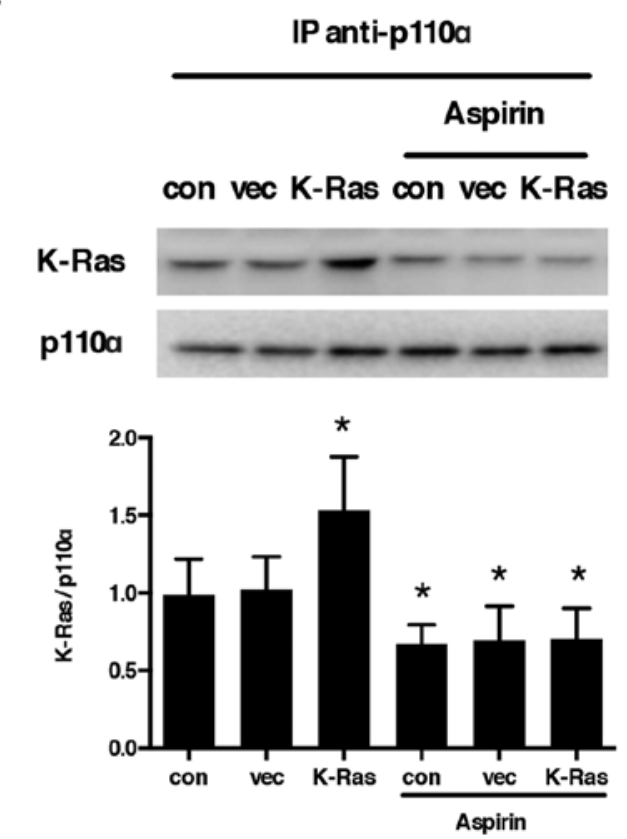

B
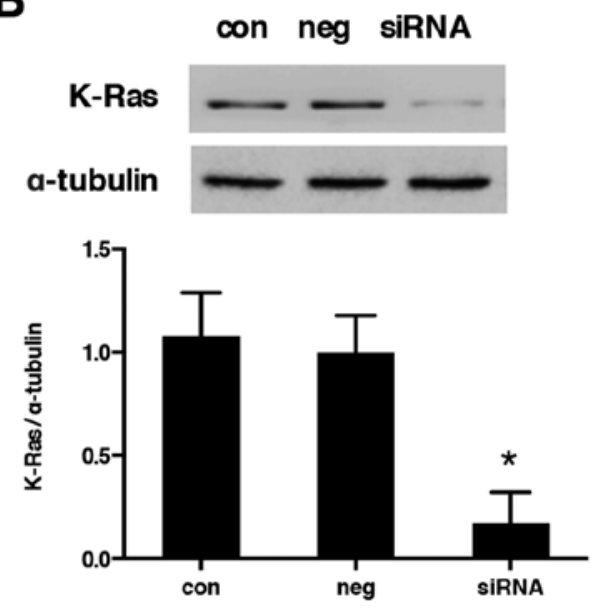

D
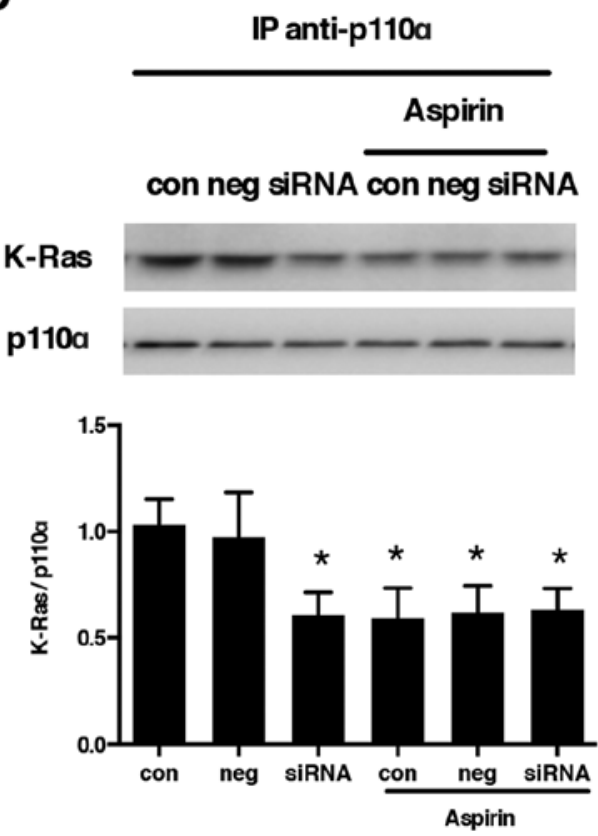

Figure 4. K-Ras-p1 $10 \alpha$ interaction is regulated by K-Ras expression under aspirin treatment. (A) Western blot analysis showed that pEnter-his-K-Ras plasmid transfection increased K-Ras expression in human uterine leiomyoma cells ( $\mathrm{n}=6,{ }^{*} \mathrm{P}<0.05$ vs con). (B) Anti-K-Ras siRNA (40 mmol/l) transfection for $48 \mathrm{~h}$ significantly decreased endogenous K-Ras protein expression in human uterine leiomyoma cells ( $\mathrm{n}=6$, ${ }^{*} \mathrm{P}<0.05$ vs con). (C) The interaction between $\mathrm{K}-\mathrm{Ras}$ and $\mathrm{p} 110 \alpha$ was increased in K-Ras overexpressed cells which was inhibited by aspirin treatment ( $\mathrm{n}=6$, ${ }^{*} \mathrm{P}<0.05$ vs con). (D) The K-Ras-p110 $\alpha$ interaction was blocked by K-Ras knockdown and aspirin had no further inhibitory effects ( $n=6,{ }^{*} \mathrm{P}<0.05$ vs con). All values represent mean \pm SD.

Effect of K-Ras on K-Ras-p110 $\alpha$ interaction under aspirin treatment. Western blotting showed that pEnter-K-Ras plasmid transfection increased K-Ras expression and antiK-Ras siRNA (40 mmol/l) transfection significantly decreased endogenous K-Ras protein expression in human uterine leiomyoma cells (Fig. 4A and B).

The association between K-Ras and p110 $\alpha$ was remarkably increased by K-Ras overexpression which could be inhibited by aspirin treatment $(4.23 \mathrm{mmol} / \mathrm{l})$ for $48 \mathrm{~h}$ (Fig. 4C). In $\mathrm{K}-\mathrm{R}$ as deletion cells, the interaction between K-Ras and p110 $\alpha$ was blocked and aspirin had no more inhibitory effect on K-Ras-p110 $\alpha$ interaction (Fig. 4D). The results showed the K-Ras-p110 $\alpha$ interaction was in inhibitory status under aspirin treatment no matter how the K-Ras protein expression was changed.
Aspirin inhibits cell proliferation via blocking the interaction of $K$-Ras with $p 110 \alpha$. In human uterine leiomyoma cells with increased K-Ras-p110 $\alpha$ interaction induced by K-Ras overexpression, the cell viability was enhanced to $132.19 \pm 4.34 \%$ which was significantly reduced to $52.91 \pm 7.87 \%$ under the treatment of aspirin ( $4.23 \mathrm{mmol} / \mathrm{l})$ for $48 \mathrm{~h}$ (Fig. 5A). Whereas K-Ras knockdown, with blocked K-Ras-p110 $\alpha$ interaction, reduced the cell growth to $55.63 \pm 8.98 \%$ compared with control cultures and aspirin did not have further inhibitory effects (Fig. 5B).

Cell cycle distribution was quantified by flow cytometry. The S-phase cell fraction in K-Ras overexpressed cells, with increased K-Ras-p110 $\alpha$ interaction, was increased from $28.45 \pm 4.01$ to $36.77 \pm 6.09 \%$ and the G0/G1-phase cell fraction was reduced from $65.59 \pm 7.52$ to $58.73 \pm 4.67 \%$, while the 

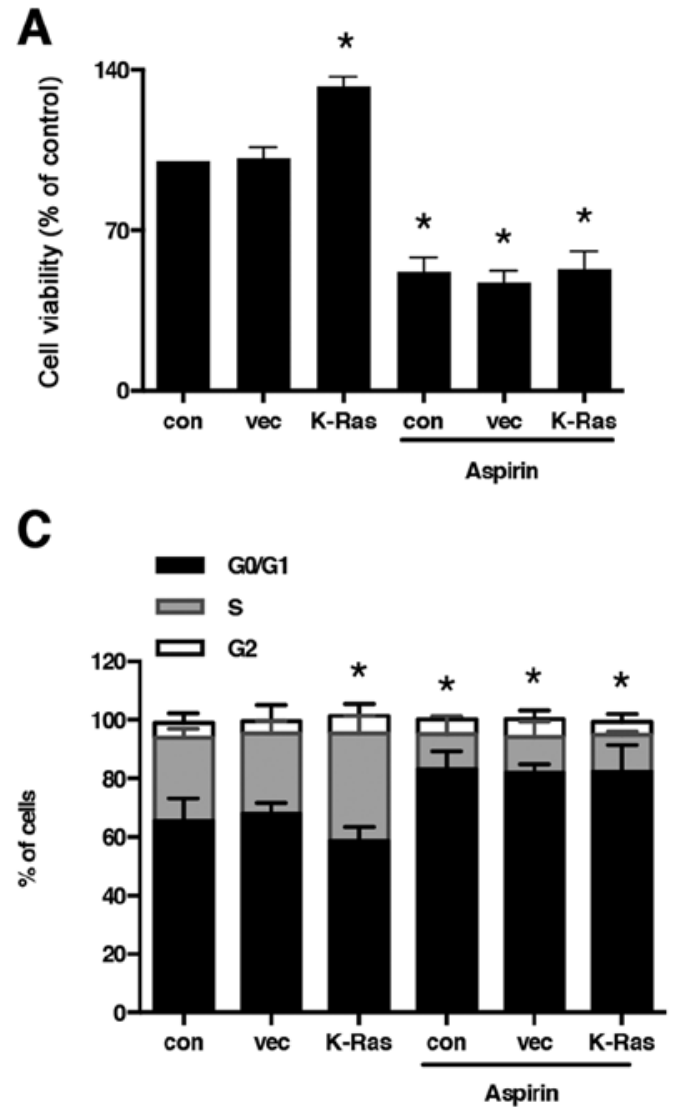
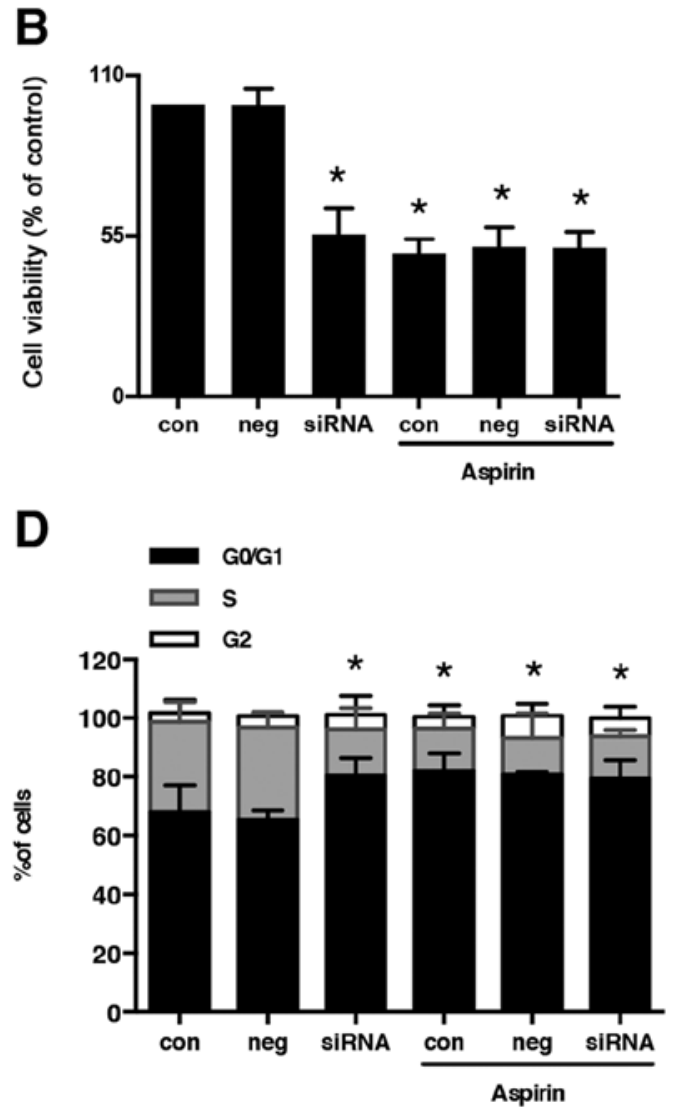

Figure 5. Effects of K-Ras-p110 $\alpha$ interaction on cellular proliferation under aspirin treatment. (A) CCK8 results showed that K-Ras overexpression promoted cell growth which was inhibited by aspirin treatment $\left(\mathrm{n}=5,{ }^{*} \mathrm{P}<0.05\right.$ vs con). (B) K-Ras deficiency inhibited cellular proliferation and aspirin had no more inhibitory effects $\left(\mathrm{n}=6,{ }^{*} \mathrm{P}<0.05\right.$ vs con). (C) Flow cytometry analysis showed that G1/S transition was promoted by K-Ras overexpression which was inhibited by aspirin treatment $\left(\mathrm{n}=6,{ }^{*} \mathrm{P}<0.05\right.$ vs con). (D) K-Ras knockdown inhibited the cell cycle transition with no more inhibitory effects under aspirin treatment $\left(\mathrm{n}=6-7,{ }^{*} \mathrm{P}<0.05\right.$ vs con). All values represent mean $\pm \mathrm{SD}$.

S-phase cell fraction was reduced to $12.67 \pm 1.09 \%$ and the G0/G1-phase cell fraction was increased to $82.34 \pm 9.01 \%$ under aspirin treatment (Fig. 5C). Furthermore, in K-Ras knockdown cells, with reduced K-Ras-p110 $\alpha$ interaction, the S-phase cell fraction was reduced from $30.73 \pm 6.78$ to $15.79 \pm 7.22 \%$ and the G0/G1-phase cell fraction was increased from $67.98 \pm 9.09$ to $80.37 \pm 6.01 \%$ and aspirin did not have further effects on cell cycle arrest (Fig. 5D). Our data indicated that the inhibitory effects on cell viability and cell cycle transition of aspirin treatment was dependent on the blockage of the interaction of K-Ras with $\mathrm{p} 110 \alpha$ in human uterine leiomyoma cells.

Effect of K-Ras-p110 $\alpha$ interaction on cell cycle regulators under treatment of aspirin. Cell cycle transition is positively regulated by cyclins and cyclin-dependent kinases. To explore the molecular mechanism by which K-Ras-p110 $\alpha$ interaction affects $\mathrm{G} 1 / \mathrm{S}$ transition, we analyzed the proteins regulating cell cycle progression including cyclin D1 and CDK2. We found that the expression of cyclin D1 and CDK2 was enhanced in K-Ras overexpression group in which the interaction of $\mathrm{K}-\mathrm{Ras}$ and $\mathrm{p} 110 \alpha$ was increased while the protein expression was remarkably reduced under aspirin treatment (Fig. 6A). In addition, K-Ras deletion made reduction in expression of cyclin D1 and CDK2 compared with control group and aspirin had no more effects in reduction of cyclin D1 and CDK2 that was attributed to the reduced association of K-Ras and p110 $\alpha$ (Fig. 6B). The data suggested that aspirin-induced inhibition on cell growth and cell cycle transition via cell cycle regulators was K-Ras-p110 $\alpha$ interaction-dependent.

PI3K/Akt signaling pathway was involved in aspirin-induced inhibitory effects on cell proliferation. In K-Ras overexpressed cells with the increase in K-Ras-p110 $\alpha$ interaction, the levels of phosphorylated PI3K p85 and phosphorylated Akt were enhanced while the phosphorylated protein expression was decreased in aspirin treatment (Fig. 7A). On the contrary, in K-Ras knockdown cells with reduced K-Ras-p110 $\alpha$ interaction, the protein expression of phosphorylated p85 and Akt was reduced and aspirin did not have further inhibitory effects (Fig. 7B). Total proteins of PI3K p85 and Akt had no significant differences among the groups. Taken together, these results demonstrated that aspirin inhibited PI3K/Akt pathway by targeting K-Ras-p110 $\alpha$ interaction.

Inhibition of PI3K/AKT pathway by aspirin enhances caspase activation. Caspase family members have been proved to be associated with PI3K/AKT signaling pathway in cell growth $(29,30)$. Therefore, we further determined the effects of aspirin on caspase activation. In K-Ras overexpression cells, the levels of cleaved caspase-3, $-9,-8,-12$ and cleaved PARP protein expression were increased significantly by aspirin treatment (Fig. 8A). On the other hand, in K-Ras knockdown 


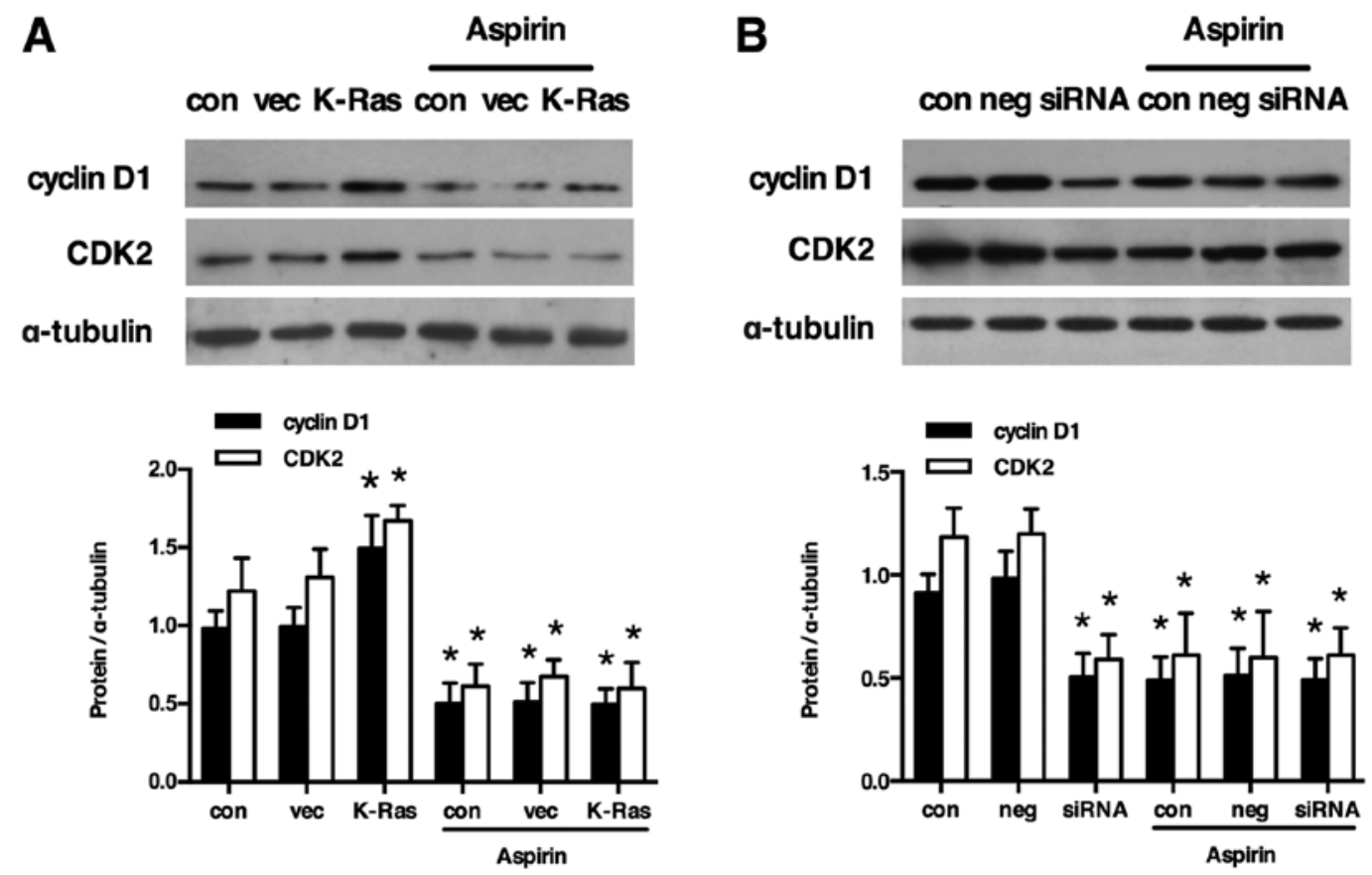

Figure 6. Effects of K-Ras-p110 $\alpha$ interaction on cell cycle regulatory proteins. (A) Representative western blot images and densitometric analysis showed that K-Ras cDNA transfection significantly increased cyclin D1 and CDK2 expression which was reduced by aspirin treatment in human uterine leiomyoma cells $\left(\mathrm{n}=5,{ }^{*} \mathrm{P}<0.05\right.$ vs con). (B) Knockdown of K-Ras reduced protein expression of cyclin D1 and CDK2 which aspirin had no more effects on ( $\mathrm{n}=6$, ${ }^{*} \mathrm{P}<0.05 \mathrm{vs}$ con). All values represent mean $\pm \mathrm{SD}$.

A
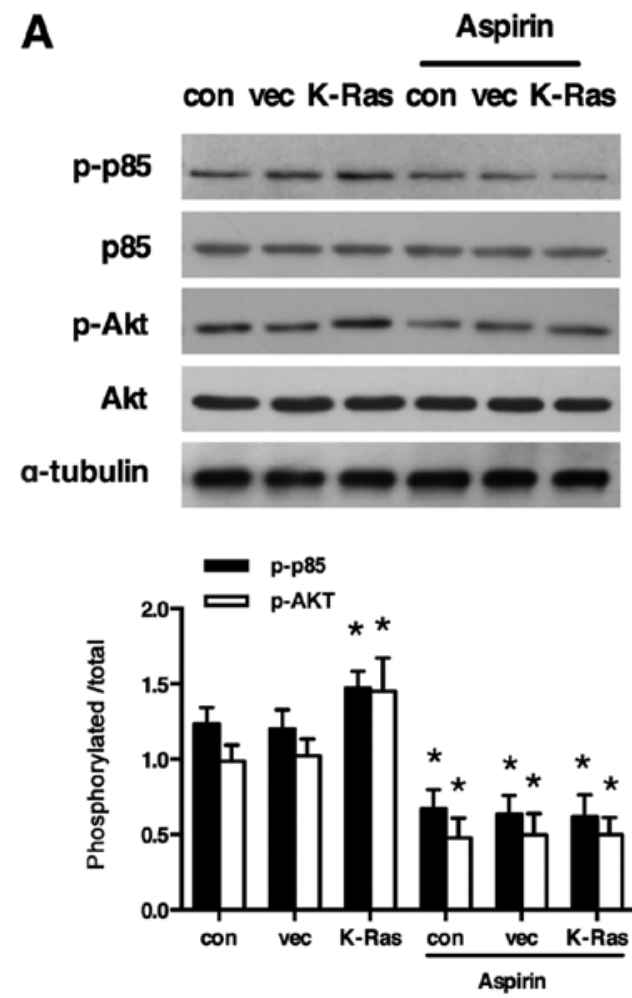

B

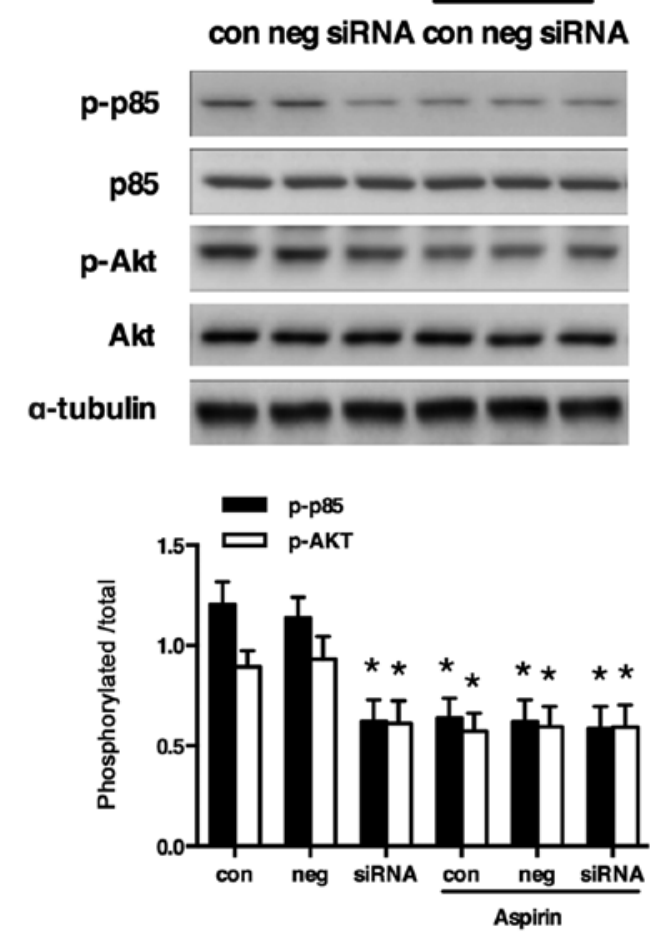

Figure 7. Aspirin inhibits human uterine leiomyoma cell proliferation through K-Ras/PI3K/Akt signaling pathway. (A) Western blot analysis showed K-Ras cDNA transfection significantly increased the phosphorylation of PI3K p85 and Akt which was inhibited by treatment of aspirin ( $\mathrm{n}=5$, ${ }^{*} \mathrm{P}<0.05 \mathrm{vs}$ con). (B) K-Ras deletion reduced the protein expression of phosphorylated PI3K p85 and Akt with no more inhibitory effects under aspirin treatment in human uterine leiomyoma cells $\left(\mathrm{n}=7-8,{ }^{*} \mathrm{P}<0.05\right.$ vs con). All values represent mean $\pm \mathrm{SD}$.

cells with reduced K-Ras-p110 $\alpha$ interaction, the protein expression of cleaved caspase- $3,-9,-8,-12$ and cleaved PARP were increased and aspirin did not have further enhancement effects (Fig. 8B). Our results indicated that aspirin enhanced caspase activation through the inhibition of PI3K/AKT signaling pathway. 
A

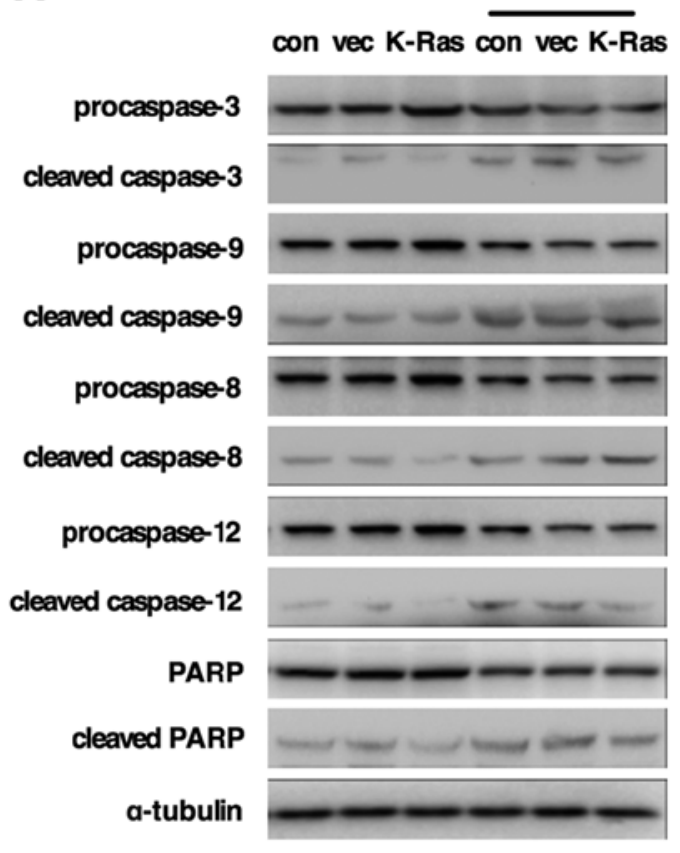

B

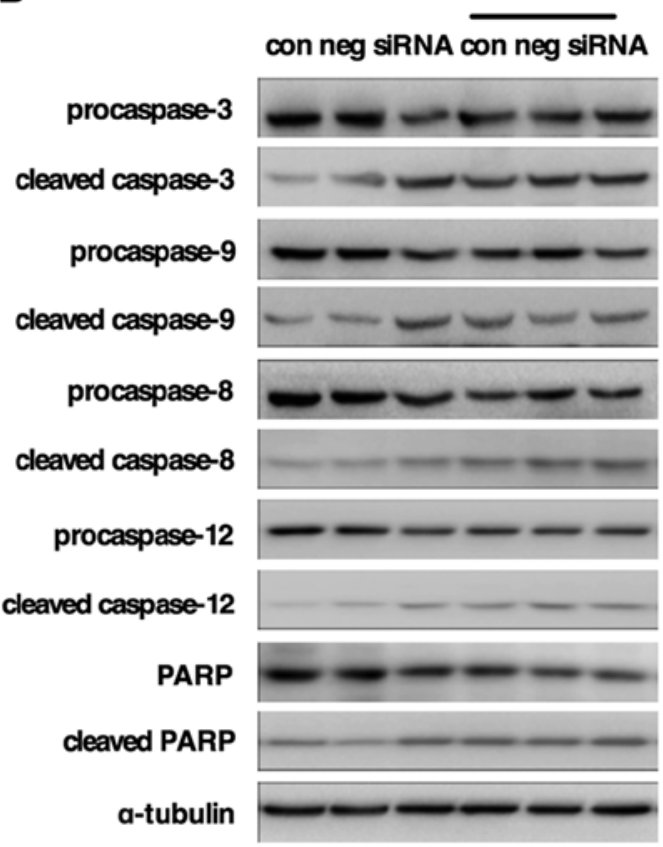

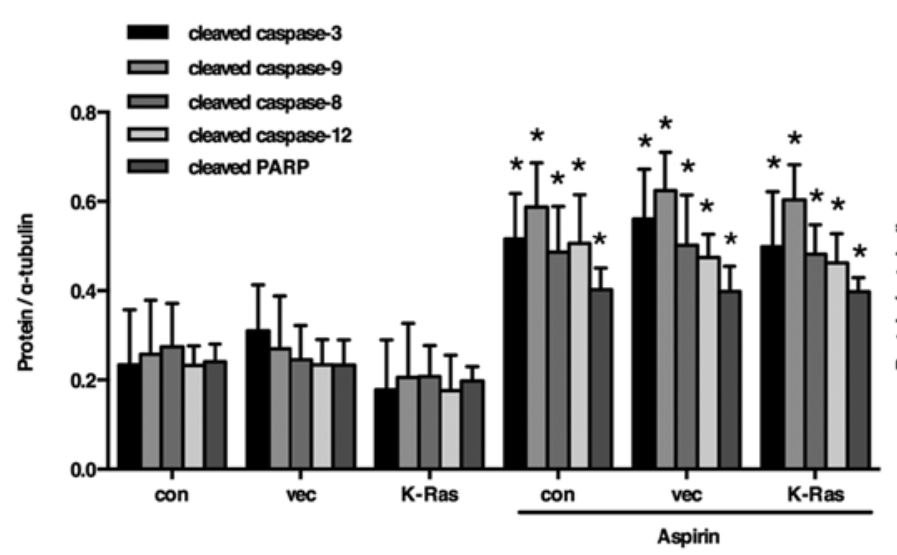

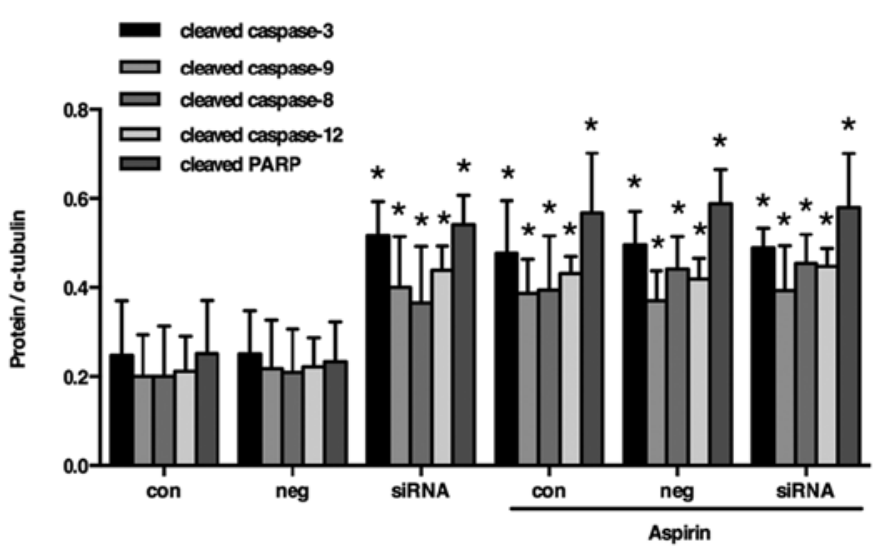

Figure 8. Caspase activation and PARP cleavage induced by aspirin are dependent on K-Ras/PI3K/Akt signaling pathway. (A) Western blot results showed in K-Ras overexpression cells, the expression of cleaved caspase- $3,-9,-8,-12$, and PRAP were increased under aspirin treatment $\left(\mathrm{n}=4\right.$, ${ }^{*} \mathrm{P}<0.05$ vs con). (B) Western blot results showed that cleaved caspase-3, $-9,-8,-12$, and PRAP were increased in K-Ras deletion human uterine leiomyoma cells and aspirin had no more enhancement effects on caspase activation and PARP cleavage ( $n=4-5,{ }^{*} \mathrm{P}<0.05$ vs con). All values represent mean \pm SD.

\section{Discussion}

In the present study, we found that aspirin inhibits the proliferation and promote cell cycle arrest via cell cycle regulators of human uterine leiomyoma cells. These effects are at least in part by downregulation of K-Ras-p110 $\alpha$ interaction and the subsequent modulation of PI3K/Akt/caspase signaling pathway.

Recent studies have demonstrated a wide variety of positive effects of aspirin on cancer therapy, however, little is known about the effects of aspirin on uterine leiomyoma. Thus, we showed that aspirin inhibited human uterine leiomyoma cell proliferation in vitro. The dose of aspirin is varied depend on different diseases, such as $75-325 \mathrm{mg} /$ day for cardiovascular disease, $\leq 325 \mathrm{mg} / \mathrm{day}$ for osteoarthritis and rheumatoid arthritis, and low dose of 75-300 mg/day for colorectal cancer and endometrial cancer (8,31-33). In addition, in vitro experiments, the effective doses of aspirin in most studies in colon, prostate or breast cancer cells vary from 1-10 mmol/1 $(26,34,35)$. Our data suggested that the $\mathrm{IC}_{50}$ value of aspirin for cell growth inhibition was $4.23 \mathrm{mmol} / \mathrm{l}$. Moreover, Juárez Olguín et al (36) demonstrated that it was safe to reach the maximum serum concentration of aspirin as high as $10 \mathrm{mmol} / \mathrm{l}$, indicating that the dose of $4.23 \mathrm{mmol} / \mathrm{l}$ in aspirin use was safe and feasible and was used for the following experiments.

PI3K along with Ras family small GTPases, mediating cell growth, differentiation, proliferation and multiple other cellular processes, are one of the most important early signaling components $(37,38)$. Ras small GTPases have been shown to directly associate with p110 catalytic subunits of PI3K through a Ras binding domain (RBD) and then activate the following PI3K/Akt pathway. It is reported that Ras is indispensable for the full activation of class I PI3Ks (39). 
Rao et al illustrated that low-dose aspirin inhibited the pancreatic carcinoma activity in $\mathrm{Kras}^{\mathrm{G} 12 \mathrm{D} /+}$ transgenic mice (40). Then we testified that aspirin dramatically blocked the interaction between K-Ras and p1 $10 \alpha$. These results indicated that aspirin might inhibit the proliferation of human uterine leiomyoma cells through reduction in K-Ras-p110 $\alpha$ interaction.

The K-Ras protein has been considered as a major target in the discovery of antitumor drugs because K-Ras mutation is commonly observed in various cancers and it lies at the apex of numerous growth regulatory cascades (41-43). Knockdown of K-Ras suppressed tumor growth while overexpression of $\mathrm{K}$-Ras led to various cancers $(44,45)$. It has been reported that several K-Ras inhibitors, including farnesyltransferase inhibitors, have been explored to lead to inhibition of wild-type K-Ras activity, growth and development (46). We found that in human uterine leiomyoma cells, K-Ras overexpression could increase the interaction of K-Ras and $\mathrm{p} 110 \alpha$ while K-Ras knockdown could inhibit the K-Ras-p110 $\alpha$ interaction. Then we used the strategy of K-Ras overexpression or K-Ras knockdown to modulate the interaction of K-Ras with $\mathrm{p} 110 \alpha$. In order to verify the role of K-Ras-p110 $\alpha$ interaction which may perform as a potential target of aspirin, we assessed the cell growth, cell cycle transition, the expression of cell cycle regulators and the activation of the following PI3K/Akt singling pathway upon overexpression or knockdown of K-Ras in human uterine leiomyoma cells. In the present study, it was demonstrated that the inhibition in cell proliferation along with the G1/S phase transition by aspirin treatment could be observed in K-Ras overexpressed cells. Furthermore, K-Ras knockdown did not have further inhibitory effects on cell growth induced by aspirin. These data demonstrated that the anti-proliferation effects of aspirin on human uterine leiomyoma cells was K-Ras-p1 $10 \alpha$ interaction-dependent. Further studies found that in K-Ras overexpressed cells, expression of cyclin D1 and CDK2 along with the upstream kinases of phosphorylated PI3K p85 and Akt were reduced while K-Ras deletion did not cause further inhibitory effects under aspirin treatment. Caspase activity has been shown to take part in modulating cell proliferation and apoptosis. Several recent observations suggest caspases exert important functions beyond that of cell apoptosis, including cellular proliferation and cell cycle progression $(47,48)$. Previous reports have suggested that the activation of caspases, including caspase- 3 , caspase- 8 and caspase-9, can be regulated by PI3K/AKT pathway $(30,49,50)$. Our data showed that in K-Ras overexpressed human uterine leiomyoma cells, the caspase activation could be increased by aspirin. Otherwise, K-Ras knockdown increased caspase activation while aspirin did not have further enhancement effects on caspase activation. These findings illustrated that the proliferation inhibition effects of aspirin on human uterine leiomyoma cells was dependent on K-Ras-p110 $\alpha$ interaction, followed by modulation of PI3K/Akt/caspase signaling pathway.

In conclusion, aspirin inhibits the proliferation of human uterine leiomyoma cells in vitro. Specifically, it inhibited cell proliferation and promoted cell cycle arrest. Furthermore, the status of downregulation of the K-Ras-p110 $\alpha$ interaction, reduction of PI3K/Akt activation significantly affected the efficacy of aspirin, which resulted in caspase activation and cyclin D1 and CDK2 degradation and eventually, cell cycle arrest and cell growth inhibition. It is noteworthy that the inhibition of K-Ras-p1 $10 \alpha$ interaction may play the most critical role. This study suggested that aspirin might be a kind of therapeutic agent for uterine leiomyoma treatment, and targeting K-Ras-p1 $10 \alpha$ interaction might provide new strategies to treat uterine leiomyoma.

\section{Acknowledgements}

This study was supported by National Natural Science Foundation of China (no. 81302771), Natural Science Foundation of Guangdong Province (no. 2014A030313087), Science and Technology program of Guangzhou City (no. 201607010255), and the Fundamental Research Funds for the Central Universities (no. 17ykzd02).

\section{References}

1. Islam MS, Protic O, Giannubilo SR, Toti P, Tranquilli AL, Petraglia F, Castellucci M and Ciarmela P: Uterine leiomyoma: Available medical treatments and new possible therapeutic options. J Clin Endocrinol Metab 98: 921-934, 2013.

2. Mehine M, Kaasinen E, Mäkinen N, Katainen R, Kämpjärvi K, Pitkänen E, Heinonen HR, Bützow R, Kilpivaara O, Kuosmanen A, et al: Characterization of uterine leiomyomas by whole-genome sequencing. N Engl J Med 369: 43-53, 2013.

3. Eltoukhi HM, Modi MN, Weston M, Armstrong AY and Stewart EA: The health disparities of uterine fibroid tumors for African American women: A public health issue. Am J Obstet Gynecol 210: 194-199, 2014.

4. Drayer SM and Catherino WH: Prevalence, morbidity, and current medical management of uterine leiomyomas. Int $\mathrm{J}$ Gynaecol Obstet 131: 117-122, 2015.

5. Bosetti C, Rosato V, Gallus S, Cuzick J and La Vecchia C: Aspirin and cancer risk: A quantitative review to 2011. Ann Oncol 23: 1403-1415, 2012.

6. Rothwell PM, Price JF, Fowkes FG,Zanchetti A, Roncaglioni MC, Tognoni G, Lee R, Belch JF, Wilson M, Mehta Z, et al: Short-term effects of daily aspirin on cancer incidence, mortality, and nonvascular death: Analysis of the time course of risks and benefits in 51 randomised controlled trials. Lancet 379: 1602-1612, 2012.

7. Thun MJ, Jacobs EJ and Patrono C: The role of aspirin in cancer prevention. Nat Rev Clin Oncol 9: 259-267, 2012.

8. Drew DA, Cao Y and Chan AT: Aspirin and colorectal cancer: The promise of precision chemoprevention. Nat Rev Cancer 16: 173-186, 2016.

9. Johnson CC, Hayes RB, Schoen RE, Gunter MJ, Huang WY and Team PT; PLCO Trial Team: Non-steroidal anti-inflammatory drug use and colorectal polyps in the Prostate, Lung, Colorectal, And Ovarian Cancer Screening Trial. Am J Gastroenterol 105: 2646-2655, 2010.

10. Gamba CA, Swetter SM, Stefanick ML, Kubo J, Desai M, Spaunhurst KM, Sinha AA, Asgari MM, Sturgeon S and Tang JY: Aspirin is associated with lower melanoma risk among postmenopausal Caucasian women: The Women's Health Initiative. Cancer 119: 1562-1569, 2013.

11. Veitonmäki T, Tammela TL, Auvinen A and Murtola TJ: Use of aspirin, but not other non-steroidal anti-inflammatory drugs is associated with decreased prostate cancer risk at the population level. Eur J Cancer 49: 938-945, 2013.

12. Rothwell PM, Wilson M, Price JF, Belch JF, Meade TW and Mehta Z: Effect of daily aspirin on risk of cancer metastasis: A study of incident cancers during randomised controlled trials. Lancet 379: 1591-1601, 2012.

13. MacDonald BT, Tamai K and He X: Wnt/beta-catenin signaling: Components, mechanisms, and diseases. Dev Cell 17: 9-26, 2009.

14. Park IS, Jo JR, Hong H, Nam KY, Kim JB, Hwang SH, Choi MS, Ryu NH, Jang HJ, Lee SH, et al: Aspirin induces apoptosis in YD-8 human oral squamous carcinoma cells through activation of caspases, down-regulation of Mcl-1, and inactivation of ERK-1/2 and AKT. Toxicol In Vitro 24: 713-720, 2010. 
15. Wang D and Dubois RN: The role of COX-2 in intestinal inflammation and colorectal cancer. Oncogene 29: 781-788, 2010.

16. Ding JH, Yuan LY, Huang RB and Chen GA: Aspirin inhibits proliferation and induces apoptosis of multiple myeloma cells through regulation of $\mathrm{Bcl}-2$ and $\mathrm{Bax}$ and suppression of VEGF. Eur J Haematol 93: 329-339, 2014.

17. Niault TS and Baccarini M: Targets of Raf in tumorigenesis. Carcinogenesis 31: 1165-1174, 2010.

18. Hong W, Abi-Raad R, Alomari AK, Hui P and Buza N: Diagnostic application of KRAS mutation testing in uterine microglandular proliferations. Hum Pathol 46: 1000-1005, 2015.

19. Lim KH and Counter CM: Reduction in the requirement of oncogenic Ras signaling to activation of PI3K/AKT pathway during tumor maintenance. Cancer Cell 8: 381-392, 2005.

20. Schubbert S, Bollag G, Lyubynska N, Nguyen H, Kratz CP Zenker M,Niemeyer CM, Molven A and Shannon K: Biochemical and functional characterization of germ line KRAS mutations. Mol Cell Biol 27: 7765-7770, 2007.

21. Shieh A, Ward AF, Donlan KL, Harding-Theobald ER, Xu J, Mullighan CG, Zhang C, Chen SC, Su X, Downing JR, et al: Defective K-Ras oncoproteins overcome impaired effector activation to initiate leukemia in vivo. Blood 121: 4884-4893, 2013.

22. Castellano E, Sheridan C, Thin MZ, Nye E, Spencer-Dene B, Diefenbacher ME, Moore C, Kumar MS, Murillo MM, Grönroos E, et al: Requirement for interaction of PI3-kinase p110 $\alpha$ with RAS in lung tumor maintenance. Cancer Cell 24: 617-630, 2013

23. Murillo MM, Zelenay S, Nye E, Castellano E, Lassailly F, Stamp G and Downward J: RAS interaction with PI3K p110o is required for tumor-induced angiogenesis. J Clin Invest 124: 3601-3611, 2014

24. di Magliano MP and Logsdon CD: Roles for KRAS in pancreatic tumor development and progression. Gastroenterology 144: $1220-1229,2013$

25. Liao X, Lochhead P, Nishihara R, Morikawa T, Kuchiba A, Yamauchi M, Imamura Y, Qian ZR, Baba Y, Shima K, et al: Aspirin use, tumor PIK3CA mutation, and colorectal-cancer survival. N Engl J Med 367: 1596-1606, 2012.

26. Turturro SB, Najor MS, Ruby CE, Cobleigh MA and Abukhdeir AM: Mutations in PIK3CA sensitize breast cancer cells to physiologic levels of aspirin. Breast Cancer Res Treat 156 33-43, 2016.

27. Di X, Yu L, Moore AB, Castro L, Zheng X, Hermon T and Dixon D: A low concentration of genistein induces estrogen receptor-alpha and insulin-like growth factor-I receptor interactions and proliferation in uterine leiomyoma cells. Hum Reprod 23: 1873-1883, 2008.

28. Gao X, Yu L, Castro L, Tucker CJ, Moore AB, Xiao H and Dixon D: An essential role of p27 downregulation in fenvalerateinduced cell growth in human uterine leiomyoma and smooth muscle cells. Am J Physiol Endocrinol Metab 303: E1025-E1035, 2012.

29. Hafizi S, Ibraimi F and Dahlbäck B: C1-TEN is a negative regulator of the Akt/PKB signal transduction pathway and inhibits cell survival, proliferation, and migration. FASEB J 19: 971-973, 2005

30. Barber AJ, Nakamura M, Wolpert EB, Reiter CE, Seigel GM, Antonetti DA and Gardner TW: Insulin rescues retinal neurons from apoptosis by a phosphatidylinositol 3-kinase/Akt-mediated mechanism that reduces the activation of caspase-3. J Biol Chem 276: 32814-32821, 2001.

31. Silverstein FE, Faich G, Goldstein JL, Simon LS, Pincus T, Whelton A, Makuch R, Eisen G, Agrawal NM, Stenson WF, et al Gastrointestinal toxicity with celecoxib vs nonsteroidal antiinflammatory drugs for osteoarthritis and rheumatoid arthritis: the CLASS study: A randomized controlled trial. Celecoxib Long-term Arthritis Safety Study. JAMA 284: 1247-1255, 2000.

32. Campbell CL, Smyth S, Montalescot G and Steinhubl SR: Aspirin dose for the prevention of cardiovascular disease: A systematic review. JAMA 297: 2018-2024, 2007.
33. Verdoodt F, Friis S, Dehlendorff C, Albieri V and Kjaer SK: Non-steroidal anti-inflammatory drug use and risk of endometrial cancer: A systematic review and meta-analysis of observational studies. Gynecol Oncol 140: 352-358, 2016

34. Pathi S, Jutooru I, Chadalapaka G, Nair V, Lee SO and Safe S Aspirin inhibits colon cancer cell and tumor growth and downregulates specificity protein $(\mathrm{Sp})$ transcription factors. PLoS One 7: e48208, 2012.

35. Olivan M, Rigau M, Colás E, Garcia M, Montes M, Sequeiros T, Regis L, Celma A, Planas J, Placer J, et al: Simultaneous treatment with statins and aspirin reduces the risk of prostate cancer detection and tumorigenic properties in prostate cancer cell lines. BioMed Res Int 2015: 762178, 2015.

36. Juárez Olguín H, Flores Pérez J, Lares Asseff I, Loredo Abdalá A and Carbajal Rodríguez L: Comparative pharmacokinetics of acetyl salicylic acid and its metabolites in children suffering from autoimmune diseases. Biopharm Drug Dispos 25: 1-7, 2004.

37. Cantley LC: The phosphoinositide 3-kinase pathway. Science 296: 1655-1657, 2002.

38. Gupta S, Ramjaun AR, Haiko P, Wang Y, Warne PH, Nicke B, Nye E, Stamp G, Alitalo K and Downward J: Binding of ras to phosphoinositide 3-kinase p110alpha is required for ras-driven tumorigenesis in mice. Cell 129: 957-968, 2007.

39. Yang HW, Shin MG, Lee S, Kim JR, Park WS, Cho KH, Meyer T and Heo WD: Cooperative activation of PI3K by Ras and Rho family small GTPases. Mol Cell 47: 281-290, 2012.

40. Rao CV, Mohammed A, Janakiram NB, Li Q, Ritchie RL, Lightfoot S, Vibhudutta A and Steele VE: Inhibition of pancreatic intraepithelial neoplasia progression to carcinoma by nitric oxide-releasing aspirin in p48(Cre/+)-LSL-Kras(G12D/+) mice. Neoplasia 14: 778-787, 2012.

41. Downward J: Targeting RAS signalling pathways in cancer therapy. Nat Rev Cancer 3: 11-22, 2003

42. Gelb MH, Brunsveld L, Hrycyna CA, Michaelis S, Tamanoi F, Van Voorhis WC and Waldmann H: Therapeutic intervention based on protein prenylation and associated modifications. Nat Chem Biol 2: 518-528, 2006.

43. Zimmermann G, Papke B, Ismail S, Vartak N, Chandra A, Hoffmann M, Hahn SA, Triola G, Wittinghofer A, Bastiaens PI, et al: Small molecule inhibition of the KRAS-PDEd interaction impairs oncogenic KRAS signalling. Nature 497: 638-642, 2013.

44. Pylayeva-Gupta Y, Grabocka E and Bar-Sagi D: RAS oncogenes: Weaving a tumorigenic web. Nat Rev Cancer 11: 761-774, 2011.

45. Sunaga N, Shames DS, Girard L, Peyton M, Larsen JE, Imai H, Soh J, Sato M, Yanagitani N, Kaira K, et al: Knockdown of oncogenic KRAS in non-small cell lung cancers suppresses tumor growth and sensitizes tumor cells to targeted therapy. Mol Cancer Ther 10: 336-346, 2011.

46. Lerner EC, Zhang TT, Knowles DB, Qian Y, Hamilton AD and Sebti SM: Inhibition of the prenylation of K-Ras, but not H- or $\mathrm{N}$-Ras, is highly resistant to CAAX peptidomimetics and requires both a farnesyltransferase and a geranylgeranyltransferase I inhibitor in human tumor cell lines. Oncogene 15: 1283-1288, 1997.

47. Los M, Stroh C, Jänicke RU, Engels IH and Schulze-Osthoff K: Caspases: More than just killers? Trends Immunol 22: 31-34, 2001.

48. Song R, Mahidhara RS,Zhou Z,Hoffman RA,Seol DW,FlavellRA, Billiar TR, Otterbein LE and Choi AM: Carbon monoxide inhibits $\mathrm{T}$ lymphocyte proliferation via caspase-dependent pathway. J Immunol 172: 1220-1226, 2004.

49. Cardone MH, Roy N, Stennicke HR, Salvesen GS, Franke TF, Stanbridge E, Frisch S and Reed JC: Regulation of cell death protease caspase-9 by phosphorylation. Science 282: 1318-1321, 1998.

50. Uriarte SM, Joshi-Barve S, Song Z, Sahoo R, Gobejishvili L, Jala VR, Haribabu B, McClain C and Barve S: Akt inhibition upregulates FasL, downregulates c-FLIPs and induces caspase-8-dependent cell death in Jurkat T lymphocytes. Cell Death Differ 12: 233-242, 2005. 